\title{
Azithromycin in Coronavirus Disease-19: What We Know?
}

\author{
A. D. Agarwal* \\ Shri Prakashchand Jain College of Pharmacy and Research, Jamner, Maharashtra, India
}

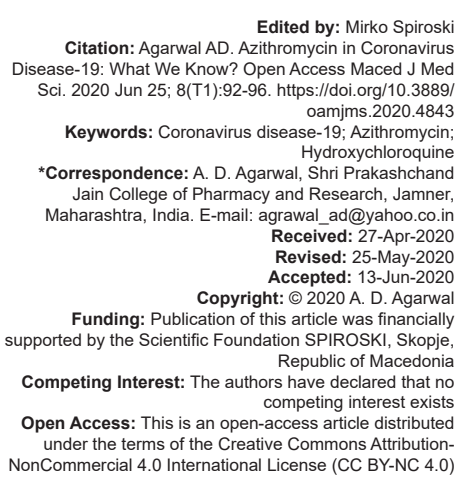

Edited by: Mirko Spirosk Citation: Agarwal AD. Azithromycin in Coronavirus Disease-19: What We Know? Open Access Maced J Med Sci. 2020 Jun 25; 8(T1):92-96. https://doi.org/10.3889/ Keywords: Coronavirus disease-19; Azithromycin Hydroxychloroquine Correspondence: A. D. Agarwal, Shri Prakashchand Jain College of Pharmacy and Research, Jamner, Maharashtra, India. E-mail: agrawal_ad@yahoo.co.in Received: 27-Apr-2020 Revised: 25-May-2020 Accepted: 13-Jun-2020 Copyright: ๑ 2020 A. D. Agarwal Funding: Publication of this article was financially pported by the Scientific Foundation SPIROSKI, Skopje, Republic of Macedonia Competing Interest: The authors have declared that no
competing interest exists under the terms of the Creative Commons AttributionNonCommercial 4.0 International License (CC BY-NC 4.0)

\begin{abstract}
Azithromycin (AZM) is a broad-spectrum antibiotic with anti-inflammatory and immunomodulatory properties. It is particularly used in chronic lung diseases including chronic obstructive pulmonary disease, asthma, interstitial lung diseases, bronchiectasis, and cystic fibrosis. AZM has not approved for the treatment of viral infections, but some study supported its antiviral activity. Recently, few studies are emphasized used AZM in combination with chloroquine/ hydroxychloroquine for the treatment of novel coronavirus disease-2019 (COVID-19). The present review highlighted uses, dosage, and adverse effects of AZM in COVID-19 based on available literature.
\end{abstract}

\section{Introduction}

An outbreak of coronavirus disease-2019 occurred in Wuhan, China in the month of December 2019 and rapidly spread across the world [1], [2]. On March 11, 2020, the WHO declared COVID-19 as a pandemic disease [3]. In an early stage, infection is characterized mainly by respiratory symptoms such as cough, sore throat, fever, and fatigue [4]. On later stage, high viral replication, high inflammatory activity, and exacerbated immune response lead to a "cytokine storm," which is responsible for complications, such as severe pneumonia and acute respiratory distress syndrome [5], with increased requirement of ventilatory support and intensive care unit admission [6]. About $80 \%$ of patients have mild disease and the overall case-fatality rate is about $2.3 \%$ but reaches $8.0 \%$ in patients aged $70-79$ years and $14.8 \%$ in those aged $\geq 80$ years, but major concern is that number of asymptomatic carriers in the population, and thus, the mortality rate is probably overestimated [7]. Therefore, there is an urgent need for an effective treatment to treat symptomatic patients and decrease the duration of virus carriage to limit the transmission in the community.

Till date, there is no specific treatment which is available to treat COVID-19. However, the backbone of the treatment strategy for
COVID-19 is good quality supportive care as in any viral pneumonia. There is no current evidence from randomized controlled trial to recommend any specific anti-COVID-19 treatment for patients with suspected or confirmed COVID-19 infection. The clinicians are using various drugs such as antiviral drugs that include inhibitors against protease, integrase, and polymerase enzymes based on anecdotal data and some recent publications. Moreover, antiviral effects of azithromycin (AZM) have been attracted considerable attention [8].

There are various treatments being used to control COVID-19 based on previous experiences with other viral infections. In the present review, we aim to summarize the uses of AZM in COVID-19.

\section{Materials and Methods}

\section{Data sources}

We performed thorough literature search on published studies between January 1, 2020, and April 15, 2020. PubMed and Google Scholar databases were used to find articles providing information on the efficacy and safety of AZM in patients with COVID-19. No language restrictions were imposed. 


\section{Inclusion and exclusion criteria}

The studies which describe used of AZM in COVID-19 and previous epidemic viruses such Ebola, severe acute respiratory syndrome, and Middle-East respiratory syndrome were selected. Meanwhile, studies which (a) duplicate publications, (b) full articles not available, (c) literature reviews, and (d) do not provided sufficient information or support regarding their recommendation of their proposed drugs or treatment process were excluded from the study.

\section{Results}

A total of 170 articles initially identified. After removing duplicates, checking title, abstract, and full text 30 were found eligible based on the predetermined exclusion and inclusion criteria for this study. Among these three articles were relevant which showed used of AZM in COVID-19 patients as summarized in Table 1 while rest of all articles were used for basic information.

\section{Discussion}

\section{$A Z M$}

AZM is a macrolide antibiotic with a 15 -membered lactone ring. It is broad-spectrum antibiotics with long serum half-life near about 68 $h$ and large volume of distribution [9]. AZM has excellent tissue penetration. In infected tissues, AZM concentrations are about 300-fold higher than in plasma, due to recruitment of leukocytes at the site of infection [10]. It also has anti-inflammatory activity, decreases pro-inflammatory cytokine and hastening of the macrophages phagocytosis ability [11]. Due to its antibacterial and anti-inflammatory effects, it is used for many chronic lung diseases including chronic obstructive pulmonary disease, asthma, interstitial lung diseases, bronchiectasis, and cystic fibrosis [12].

\section{$A Z M$ as antiviral}

Azithromycin effective against rhinovirus, respiratory syncytial virus, influenza virus, Zika virus and Ebola viruses [13], [14], [15], [16]. The mechanism is unknown. The multiple mechanisms have been proposed for antiviral activity observed with AZM. The antiviral activity may be mediated by amplification of the host's interferon (IFN) pathway by inducing pattern recognition receptors, IFNs, and IFN-stimulated genes that lead to a reduction of viral replication [17], by directly acting on bronchial epithelial cells which reduce mucus secretion (19). Moreover, a recent quantum mechanical modeling suggests a potential role of AZM in COVID-19 by interfering with viral entry through binding interaction between coronavirus spike protein and host receptor angiotensin-converting enzyme-2 protein; further, experimental work on this is necessary to confirm the model [18].

\section{Clinical study}

The symptoms of COVID-19 are similar to those seen in these lung infections; therefore, it is not surprising that AZM treatment was initiated early in the current pandemic of COVID-19. The use of AZM in 25 of 138 patients who were suffer from COVID-19 in Wuhan, China, reported in a recent JAMA article [19].

\section{First French clinical study}

A French confirmed COVID-19 positive; 36 patients $(n=20$ in treatment group and $n=16$ in control group) were enrolled in an open-label nonrandomized clinical trial. In the treatment group, 600 mg HCQ daily was given to patients and their viral load in nasopharyngeal swabs was tested daily. On basis of clinical presentation of patients, six patients received AZM (500 mg on day 1 followed by $250 \mathrm{mg} /$ day for the next 4 days) to prevent bacterial superinfection under daily electrocardiogram (ECG) control. Untreated patients from another center and cases refusing the protocol were included as negative controls. The presence and absence of virus at day 6 post-inclusion was considered the end point. The combination of hydroxychloroquine and AZM results in negative PCR results in nasopharyngeal samples was significantly

Table 1: Clinical study of azithromycin in COVID-19

\begin{tabular}{|c|c|c|c|c|c|}
\hline Study population & Sample size & Study design & Treatments & Results & Reference \\
\hline COVID-19 & $\begin{array}{l}\mathrm{n}=36 \\
\text { Treatment group } \mathrm{n}=20 \\
\text { Control group } \mathrm{n}=16\end{array}$ & $\begin{array}{l}\text { Observational open- } \\
\text { label non-randomized } \\
\text { clinical trial }\end{array}$ & $\begin{array}{l}\text { HCQ } 200 \mathrm{mg}, \text { TID } \times 10 \text { days } \\
\text { HCQ+AZM (500 mg D1 and } \\
250 \mathrm{mg} \text { D2-5) }\end{array}$ & $\begin{array}{l}\text { At day } 6 \text { post-inclusion, virologically cured } \\
\text { HCQ+AZM: } 100 \% \\
\text { HCQ: } 57.1 \% \\
\text { Control: } 12.5 \% \\
\text { p<0.001 }\end{array}$ & 20 \\
\hline COVID-19 & $\mathrm{n}=80$ & $\begin{array}{l}\text { Uncontrolled } \\
\text { non-comparative } \\
\text { observational }\end{array}$ & $\begin{array}{l}\mathrm{HCQ} 200 \mathrm{mg}, \mathrm{TID} \times 10 \\
\text { days+AZM (500 mg D1 and } \\
250 \mathrm{mg} \text { D2-5) }\end{array}$ & $\begin{array}{l}\text { Nasopharyngeal viral load tested by } \mathrm{qPCR} ; 83 \% \text { negative at day } \\
7 \text { and } 93 \% \text { at day } 8 \\
\text { Virus cultures from patient respiratory samples were negative in } \\
97.5 \% \text { of patients at day } 5\end{array}$ & 21 \\
\hline $\begin{array}{l}\text { Suspected } \\
\text { COVID-19; flu-like } \\
\text { symptoms }\end{array}$ & $\begin{array}{l}n=636 \\
\text { Treatment group } n=412 \\
\text { Control group } n=224\end{array}$ & $\begin{array}{l}\text { Observational open- } \\
\text { label non-randomized }\end{array}$ & $\begin{array}{l}\text { HCQ } 800 \mathrm{mg} \text { on D1 and } \\
400 \mathrm{mg} \text { D2-D7+AZM } 500 \\
\text { mg D1-D5 }\end{array}$ & $\begin{array}{l}\mathrm{HCQ}+\mathrm{AZM}: 1.9 \% \text { of patients required hospitalization Control: } \\
5.4 \% \text { of patients required hospitalization }(\mathrm{p}<0.0001) \\
\text { Patients treated before versus after day } 7 \text { of symptoms required } \\
\text { less hospitalization }(1.17 \% \text { and } 3.2 \% \text {, respectively, } \mathrm{p}<0.001)\end{array}$ & 22 \\
\hline
\end{tabular}


different between the two groups at days 3-4-5 and 6 post-inclusion. At day 6 post-inclusion, 100\% of patients treated with hydroxychloroquine and AZM were virologically cured compared to $57.1 \%$ in patients treated with hydroxychloroquine only and $12.5 \%$ in the control group ( $p<0.001)$. Therefore, addition of AZM to hydroxychloroquine treatment results in significantly viral load reduction/disappearance in COVID-19 patients. The limitations of study are small sample size, limited long-term outcome follow-up, and dropout of six patients from the study [20].

\section{Second French clinical study}

Gautret et al. conducted an uncontrolled non-comparative observational study in a cohort of 80 confirmed COVID-19 patients. All patients received $600 \mathrm{mg} /$ day oral hydroxychloroquine sulfate for 10 days combined with AZM (500 mg on day 1 followed by $250 \mathrm{mg} /$ day for the next 4 days). Patients with pneumonia and NEWS score $\geq 5$, a broad-spectrum antibiotic (ceftriaxone), were added to hydroxychloroquine and AZM. Twelve-lead ECGs were performed on each patient before treatment and 2 days after treatment began. The median age of patients was 52 years (ranging from 18 to 88 years) and had at least one chronic condition such as hypertension, diabetes, and chronic respiratory disease. About $81.3 \%$ of patients had favorable outcome and were discharged from unit while only $15 \%$ required oxygen therapy during their stay. A rapid fall of nasopharyngeal viral load tested by quantitative polymerase chain reaction was noted, with $83 \%$ negative at day 7 and $93 \%$ at day 8 . Virus cultures from patient respiratory samples were negative in $97.5 \%$ of patients at day 5 . Moreover, patients were able to be rapidly discharged from infectious disease unit with a mean length of stay of 5 days. Therefore, a beneficial effect of coadministration of AZM along with hydroxychloroquine observed in COVID-19 patients [21].

\section{Brazil telemedicine clinical study}

A telemedicine study was conducted in Sao Paulo, Brazil, after the pandemic was officially declared in city. Patients with persistent flu-like symptoms (suspected COVID-19 infection), persisting for a period equal to or greater than 2 days, were first evaluated by the telemedicine team or by the emergency department medical doctor. Participants who did not need immediate hospitalization and azithromycin was not contraindications were invited to participate in the study. A total of 636 symptomatic outpatients enrolled in the study. The treatment group $(n=412)$ received hydroxychloroquine $800 \mathrm{mg}$ on the $1^{\text {st }}$ day and $400 \mathrm{mg}$ for another 6 days and AZM $500 \mathrm{mg}$ once daily for 5 days. A total of 224 patients who refused to medications served as control group. The swab laboratory was not mandatory and chest computed tomography was performed according to medical judgment. All patients were followed daily by telemedicine consultations until the $5^{\text {th }}$ day of symptoms, after that, patients were contacted twice a day until the $14^{\text {th }}$ day of initial symptoms. In the treatment group, $1.9 \%$ of patients required hospitalization as compared to $5.4 \%$ of patients in the control group ( $p<0.0001)$ which indicates 2.8 times greater need for hospitalization compared to those without medication. An absolute risk reduction is $3.5 \%$ and a number needed to treat (NNT) is 28 to prevent one hospitalization. The patients treated before versus after day 7 of symptoms required less hospitalization $(1.17 \%$ and $3.2 \%$, respectively, $p<0.001)$. Comparing the early treatment ( $<7$ days of symptoms) to those without treatment (control group), the NNT was 23. Therefore, empirical treatment of hydroxychloroquine and AZM for suspected cases of COVID-19 reduces the need for hospitalization [22]. To sum up, Table 1 shows clinical studies of AZM in COVID-19.

\section{Adverse events}

Common side effects of AZM include abdominal pain, diarrhea, constipation, nausea, dizziness, headaches, photosensitivity, or a skin rash [23]. Tinnitus and even hearing loss are associated with this medication [24], [25]. It should be avoided in patients with a history of Stevens-Johnson syndrome [26] and other serious skin reactions [27] as well as those with myasthenia gravis. Prolonged cardiac repolarization and prolongation of the QT interval can occur [28]. An ECG should be performed to assess the normal heart rhythm because the medication can cause arrhythmias. Patients with abnormal QT intervals, congenital long QT syndrome, a history of torsades de pointes, bradyarrhythmias, or heart failure may be at risk for fatal QT prolongation [29]. Elderly patients are more at risk. Abnormal liver function tests, hepatitis, hepatic necrosis, cholestatic jaundice, and hepatic failure have been reported with its use. AZM increased levels of theophylline and aminophylline, warfarin, digoxin, phenytoin, and statins. Nelfinavir increases serum concentration of $A Z M$, so those receiving single oral doses need to have liver enzyme tests and hearing monitored [30].

\section{Conclusion}

The literature presented here provides a significant role of AZM in COVID-19 when combined with $\mathrm{HCQ}$. It helps to reduce nasopharyngeal viral load, hospitalization and patients were able to be rapidly discharged from infectious disease unit. A well-designed randomized double-blind placebo control clinical trials are needed for further clarity and evidence. Results of 
near future researches will assess safety data of its use to guide clinical usage during this pandemic.

\section{References}

1. Lai CC, Shih TP, Ko WC, Tang HJ, Hsueh PR. Severe acute respiratory syndrome coronavirus 2 (SARS-CoV-2) and coronavirus disease-2019 (COVID-19): The epidemic and the challenges. Int J Antimicrob Agents. 2020;55(3):105924. https:// doi.org/10.1016/j.jjantimicag.2020.105924

PMid:32081636

2. Wang LS, Wang YR, Ye DW, Liu QQ. A review of the 2019 novel coronavirus (COVID-19) based on current evidence. Int J Antimicrob Agents. 2020;2020:105948.

PMid:32201353

3. WHO Director-general's Opening Remarks at the Media Briefing on COVID-19. Available from: https://www.who.int/dg/speeches/ detail/who-director-general-s-opening-remarks-at-the-mediabriefing-on-COVID-19-11-march-2020. [Last accessed on 2020 Mar 11]. https://doi.org/10.1093/ww/9780199540884.013. u20123

4. Guan W, Ni Z, Hu Y, Liang W, Ou C, He J, et al. Clinical characteristics of coronavirus disease 2019 in China. N Engl J Med. 2020;382:1708-20.

5. Inciardi RM, Lupi L, Zaccone G, Italia L, Raffo M, Tomasoni D, et al. Cardiac involvement in a patient with coronavirus disease 2019 (COVID-19). JAMA Cardiol. 2020. https://doi.org/10.1001/ jamacardio.2020.1096 PMid:32219357

6. Huang $\mathrm{C}$, Wang $\mathrm{Y}, \mathrm{Li} \mathrm{X}$, Ren L, Zhao J, Hu Y, et al. Clinical features of patients infected with 2019 novel coronavirus in Wuhan, China. Lancet. 2020;395(10223):497-506. https://doi. org/10.1016/s0140-6736(20)30183-5

PMid:31986264

7. Wu Z, McGoogan JM. Characteristics of and important lessons from the coronavirus disease 2019 (COVID-19) outbreak in China: Summary of a report of 72314 cases from the Chinese center for disease control and prevention. JAMA. 2020;323(13):12391242. https://doi.org/10.1001/jama.2020.2648

PMid:32091533

8. Dayer MR. Old drugs for newly emerging viral disease, COVID19: Bioinformatic Prospective; 2003. https://www.arxiv.org/ftp/ arxiv/papers/2003/2003.04524.pdf. [Last accessed on $2020 \mathrm{Apr}$ 01]. https://doi.org/10.14744/iacapaparxiv.2020.20001

9. Rapp RP. Pharmacokinetics and pharmacodynamics of intravenous and oral azithromycin: Enhanced tissue activity and minimal drug interactions. Ann Pharmacother. 1998;32(78):785-93. https://doi.org/10.1345/aph.17299

\section{PMid:9681095}

10. Liu P, Allaudeen H, Chandra R, Phillips K, Jungnik A, Breen JD, et al. Comparative pharmacokinetics of azithromycin in serum and white blood cells of healthy subjects receiving a single-dose extended-release regimen versus a 3-day immediate-release regimen. Antimicrob Agents Chemother. 2007;51(1):103-9. https://doi.org/10.1128/aac.00852-06

PMid:17060516

11. Feola DJ, Garvy BA, Cory TJ, Birket SE, Hoy H, Hayes D Jr., et al. Azithromycin alters macrophage phenotype and pulmonary compartmentalization during lung infection with Pseudomonas. Antimicrob Agents Chemother. 2010;54(6):2437-47. https://doi. org/10.1128/aac.01424-09

\section{PMid:20231397}

12. Li H, Liu DH, Chen LL, Zhao Q, Yu YZ, Ding JJ, et al. Metaanalysis of the adverse effects of long-term azithromycin use in patients with chronic lung diseases. Antimicrob Agents Chemother. 2014;58(1):511-7. https://doi.org/10.1128/ aac. $02067-13$

PMid:24189261

13. Min JY, Jang YJ. Macrolide therapy in respiratory viral infections. Mediators Inflamm. 2012;2012:649570.

PMid:22719178

14. Tran $D H$, Sugamata $R$, Hirose $T$, Suzuki $S$, Noguchi $Y$, Sugawara A, et al. Azithromycin, a 15-membered macrolide antibiotics, inhibits influenza $\mathrm{A}(\mathrm{H} 1 \mathrm{~N} 1)$ pdm09 virus infection by interfering with virus internalization process. J Antibiot. 2019;72:759-68. https://doi.org/10.1038/s41429-019-0204-x

15. Bosseboeuf $E$, Aubry $M$, Nhan T, Pina JJ, Rolain JM, Raoult $\mathrm{D}$, et al. Azithromycin inhibits the replication zika virus. J Antivir Antietrovir. 2018;10(1):6-11. https://doi. org/10.4172/1948-5964.1000173

16. Madrid PB, Panchal RG, Warren TK, Shurtleff AC, Endsley AN, Green $\mathrm{CE}$, et al. Evaluation of Ebola virus inhibitors for drug repurposing. ACS Infect Dis. 2015;1(7):317-26. https://doi. org/10.1021/acsinfecdis.5b00030

\section{PMid:27622822}

17. Menzel M, Akbarshahi H, Bjermer L, Uller L. Azithromycin induces anti-viral effects in cultured bronchial epithelial cells from COPD patients. Sci Rep 2016;6:28698. https://doi. org/10.1038/srep28698

PMid:27350308

18. Sandeep S, McGregor K. Energetics based modeling of hydroxychloroquine and azithromycin binding to the SARSCoV-2 spike (S) protein-ACE2 complex. ChemRxiv. 2020;2020. https://doi.org/10.26434/chemrxiv.12015792.v2

19. Wang D, Hu B, Hu C, Zhu F, Liu X, Zhang J, et al. Clinical characteristics of 138 hospitalized patients with 2019 novel coronavirus-infected pneumonia in Wuhan, China. JAMA. 2020;323(11):1061-9. https://doi.org/10.1001/jama.2020.1585

20. Gautret $P$, Lagier JC, Parola P, Hoang VT, Meddeb L, Mailhe M, et al. Hydroxychloroquine and azithromycin as a treatment of COVID-19: Results of an open-label non-randomized clinical trial. Int J Antimicrob Agents. 2020;2020:105949. https://doi. org/10.1016/j.jantimicag.2020.105949

21. Gautret $P$, Lagier JC, Parola P, Hoang VT, Meddeb L, Sevestre J, et al. Clinical and microbiological effect of a combination of hydroxychloroquine and azithromycin in 80 COVID-19 patients with at least a six-day follow up: A pilot observational study. Travel Med Infect Dis. 2020;34:101663. https://doi.org/10.1016/j. tmaid.2020.101663

PMid:32289548

22. Esper RB, Silva RS, Oikawa FT, Castro MM, Razuk-Filho A Batista PB Jr., et al. Empirical Treatment with Hydroxychloroquine and Azithromycin for Suspected Cases of COVID-19 Followed-up by Telemedicine Dropbox; 2020. Available from: http://www.dropbox.com/s/5qm58cd4fneeci2/2020.04.15\%20 journal\%20manuscript $\% 20$ final.pdf?dl=0. [Last accessed on 2020 Apr 20].

23. Azithromycin Side Effects. Available from: https://www.drugs $\mathrm{com} / \mathrm{sfx} /$ azithromycin-side-effects.html. [Last accessed on 2020 Mar 27].

24. Mick P, Westerberg BD. Sensorineural hearing loss as a probable serious adverse drug reaction associated with lowdose oral azithromycin. J Otolaryngol. 2007;36(5):257-63. https://doi.org/10.2310/7070.2007.0047 PMid:17963663

25. Ress BD, Gross EM. Irreversible sensorineural hearing loss as a result of azithromycin ototoxicity: A case report. 
Ann Otol Rhinol Laryngol. 2000;109(4):435-7. https://doi. org/10.1177/000348940010900416

PMid:11201801

26. Brkljacić N, Gracin S, Prkacin I, Sabljar-Matovinović M, Mrzljak A, Nemet Z. Stevens-Johnson syndrome as an unusual adverse effect of azithromycin. Acta Dermatovenerol Croat. 2006;14(1):40-5.

PMid:16603101

27. Banerjee I, Mondal S, Sen S, Tripathi SK, Banerjee G. Azithromycin-induced rash in a patient of infectious mononucleosis-a case report with review of literature. J Clin Diagn Res. 2014;8(8):HD01-2. https://doi.org/10.7860/ jcdr/2014/9865.4729

PMid:25302218

28. Gibson PG, Yang IA, Upham JW, Reynolds PN, Hodge S,
James AL, et al. Effect of azithromycin on asthma exacerbations and quality of life in adults with persistent uncontrolled asthma (AMAZES): A randomised, double-blind, placebo-controlled trial. Lancet. 2017;390(10095):659-68. https://doi.org/10.1016/ s0140-6736(17)31281-3

PMid:28687413

29. Lu ZK, Yuan J, Li M, Sutton SS, Rao GA, Jacob S, et al. Cardiac risks associated with antibiotics: Azithromycin and levofloxacin. Expert Opin Drug Saf. 2015;14(2):295-303. https://doi.org/10.1 $517 / 14740338.2015 .989210$

PMid:25494485

30. National Institute of Diabetes and Digestive and Kidney Diseases. Bethesda, MD: LiverTox: Clinical and Research Information on Drug-Induced Liver Injury; 2012. Available from: https://www.ncbi.nlm.nih.gov/books/NBK548434. [Last accessed on 2020 Mar 27]. 